\title{
IMPACT ASSESSMENT STUDY ON SELECTED SPICE CROPS UNDER ACTION PLAN IN BANGLADESH
}

\author{
F. A. Huda, M. S. Islam ${ }^{1}$, H. Biswas ${ }^{2}$ and M. S. Islam ${ }^{3}$ \\ Department of Agricultural Economics, Bangladesh Agricultural University \\ Mymensingh-2202, Bangladesh
}

\begin{abstract}
To increase production and import substitution of spices, the Ministry of Agriculture has launched the 'Action Plan' by facilitating supply of improved seed, fertilizer along with training for the farmers through institutional linkages of the all-public research and extension agencies from 2002 to 2006. The study was undertaken to evaluate the impact of the Action Plan and to identify the current status of spice crops in relation to production, area, yield, consumption and marketing system in the selected area of spice crops in Bangladesh. An intensive survey of beneficiaries of the five major spices namely onion, garlic, ginger, chili and turmeric from the four region of Bangladesh under Action Plan was done to have necessary information during January to June 2006. Among five major spices, area production, import, demand and net availability of onion occupied higher position compared to others. From the benchmark period (2001-2002) area, production and yield of onion increased from 37 thousand hectare, 150 thousand metric ton and 4 ton/hectare to 141 thousand hectare, 754 thousand metric ton and 5.35 ton/hectare respectively. As a consequence net availability and per capita consumption increased. Area, production, yield, per capita availability and net availability of garlic, ginger, chili and turmeric also increased from the benchmark period to 2005. It was observed that The Action Plan has been successfully generated positive impact on cropping system and socio-economic condition. Estimation of financial profitability shown that ginger appeared to be highly profitable spice crops having net return Tk. 2,82,011 per hectare followed by chili (Tk. 71,441 per hectare), turmeric (Tk. 65,423 per hectare), garlic (Tk. 50,281 per hectare) and onion (Tk. 38,281 per hectare) accordingly.
\end{abstract}

Key words : Impact, Assessment, Action plan, Spice crop

\section{INTRODUCTION}

\section{Backgrounds of the study}

Spices are common item in food manus especially in Indian Sub-continent. International Standards Organization (ISO) listed 107 varieties of spices in the World. Spices are extensively used for nutritional merits, flavor, making food item tasty and delicious and

\footnotetext{
1 Assistant Professor, Department of Horticulture, Bangladesh Agricultural University, Mymensingh-2202, Bangladesh

2 Assistant Commissioner (Land) Ramu, Cox's Bazar. 4: Assistant Professor, Uttora University, Dhaka
} 
preserving food. Traditionally, Bangladeshi food manus are spices dominated. The typical subsistence cropping system in Bangladesh was spices based. There are about 27 varieties of spices grown in Bangladesh (Spices Research Centre, 2005). Among them five major varieties of spice namely onion, garlic, chili, ginger and turmeric are common in Bangladesh cropping system. For food securities and policy support for rice culture, the areas under spices crops are gradually decreasing (Alam 2005). Beside these, increase in population as well as diverse ways of using spices lead to increase demand for spices.

Annual productions of the five major varieties of spices namely onion, garlic, chili, ginger and turmeric are 12.25 lakh metric tones, which cover 63.15 percent of total demand. Rest of the demand is met up by importing 3.98 lakh metric tones per annum (DAE, 2005).

Studies (Elias et.al.1984) found that spices are more profitable than that of their others competitive crops. Rahman (1993) also shown that net returns of turmeric and chili production are higher than Rabi vegetables production. After considering the profitability of spice crops and with a view to reduce the import cost, Ministry of Agriculture launched an action plan entitled "Action Plan for Increasing the Production of Spices Crop in Bangladesh" in 2002.

This study investigated the socio-economic impact of intervention made by the project on spices production and examined the possibilities of import substitution and export promotion with these crops.

\section{Objectives of the study}

The study was undertaken to accomplish the following objectives:

i. to identify the current status of spice crops in relation to production, area, yield and consumption;

ii. to evaluate the impact of recent intervention made by the Action Plan on selected spice crops production system;

iii. to determine the financial profitability of production of the spice crops;

iv. to draw conclusions and formulate some recommendations for necessary interventions with a view to increasing production of spice crops.

\section{METHODOLOGY}

\section{Selection of the study site and respondents}

The study covered mainly eight districts namely Faridpur, Sylhet, Brahmanbaria, Moulobhi bazar, Pabna, Dinajpur, Nilpharamari and Jessore from four old divisions of Bangladesh. In this study, to assess the impact of five major spice crops i.e., Onion, Garlic, Ginger, Chili and Turmeric production under the" Action Plan", 208 spice crops growers were selected. 
The number of samples was 80 for Onion, 32 for Garlic, 32 for Ginger, 32 for Chili and 32 for Turmeric respectively.

The primary data were collected purposively from the four regions by using questionnaire during the period of March to May 2006. Besides these, secondary data were collected from different published and un-published sources to fulfill of the objectives of the study.

\section{Analytical techniques}

Descriptive statistics, such as frequency, percentage, rank, range, mean were used to describe mainly the socio-economic aspects as well as to assess the impact of action plan of the spice crop farmers before and after approach was used. Besides, financial analyses were done for measuring profitability of spice crops production.

\section{RESULTS AND DISCUSSIONS}

\section{Status of spice crops}

Current status of area, production demand, deficit and import of spice crops in Bangladesh

Table 1 and Fig. 1 shows that Onion occupied the highest percent of area used (44.62\%) among major five spice crops followed by Chili $(32.91 \%)$, Garlic (10.76\%), Turmeric $(8.23 \%)$ and Ginger $(3.48 \%)$ accordingly. It indicates that Onion producers are using more land and producing more onion (61.55\%) than other major five spice crops (14.45\% for Garlic, $9.31 \%$ for Chili, $8.89 \%$ for Ginger and $5.71 \%$ for Turmeric accordingly). But onion import also higher than others due to demand for this spice is higher. At the same time net availability also higher for Onion followed by Garlic, Ginger, Chili and Turmeric respectively. It appears from the table that deficit is higher for ginger and lower for garlic as well.

\section{Status of onion}

Year wise key indicators of onion summarized in the Table 2. At the time of execution of action plan 2001-2002 (benchmark period), the total production was 150 thousand metric ton under the area of 37 thousand hectare. In 2004-2005, production went up to 754 thousand metric ton under the area of 141 thousand hectare indicates that a significant positive change in both area and production over the year. These are also supported by the increasing trend of percentage of net cultivated area under onion. At the same time, productivity goes up from 4 metric ton per hectare to 5.35 metric ton per hectare. A positive change in area, production and yield of onion ensure a notable increase in net availability as well as per capita availability for consumption. All the production activities lead to increase requirement of seed from 0.11 to 0.56 thousand metric ton. 
Table 1. Present status of area, production, demand, deficit and import of spice crops in Bangladesh (2004-2005)

\begin{tabular}{|c|c|c|c|c|c|c|}
\hline Crops & $\begin{array}{c}\text { Area } \\
\left(000^{\prime} \text { ha }\right)\end{array}$ & $\begin{array}{c}\text { Production } \\
\left(000^{`} \mathrm{MT}\right)\end{array}$ & $\begin{array}{c}\text { Import } \\
\left(000^{\prime} \mathrm{MT}\right)\end{array}$ & $\begin{array}{l}\text { Demand* } \\
\left(000^{`} \mathrm{MT}\right)\end{array}$ & $\begin{array}{c}\text { Net Availability** } \\
\left(000^{\star M T}\right)\end{array}$ & $\begin{array}{c}\text { Deficit (000 } \\
\text { ‘MT) }\end{array}$ \\
\hline Onion & $141(44.62)^{*}$ & $754(61.55)$ & 32.97 & 1460.00 & 1064.86 & 376.28 \\
\hline Garlic & 34 (10.76) & $177(14.45)$ & 22.63 & 219.0 & 195.20 & 19.36 \\
\hline Ginger & $11(3.48)$ & $110(8.98)$ & 24.29 & 219.0 & 131.54 & 80.47 \\
\hline Chili & 104(32.91) & $114(9.31)$ & 16.01 & 152.00 & 127.16 & 21.98 \\
\hline Turmeric dry & $26(8.23)$ & $70(5.71)$ & 5.59 & 110.00 & 72.09 & 34.40 \\
\hline
\end{tabular}

Source : BBS, 2004; Ministry of Agriculture GoB, 2005; *Figure in the parenthesis shows percent of total Note : * The uses of Onion, Garlic Ginger, Chili and Turmeric for the industrial purposes are not included in case of estimating demand and per capita per day demand considered for each of the crop was Onion-25.0gm, Ginger-4.00gm, Garlic-4.00gm, Turmeric-2.00gm and Chili-3.00gm respectively. For demand estimation, per capita per day demand was multiplied by total population of Bangladesh (GOB, 2005).

** Net availability estimated by multiplying $2.5 \%$ of seed wastage from gross production and adding up amount of import, then deducted export from it

$\%$ of area under spice crops
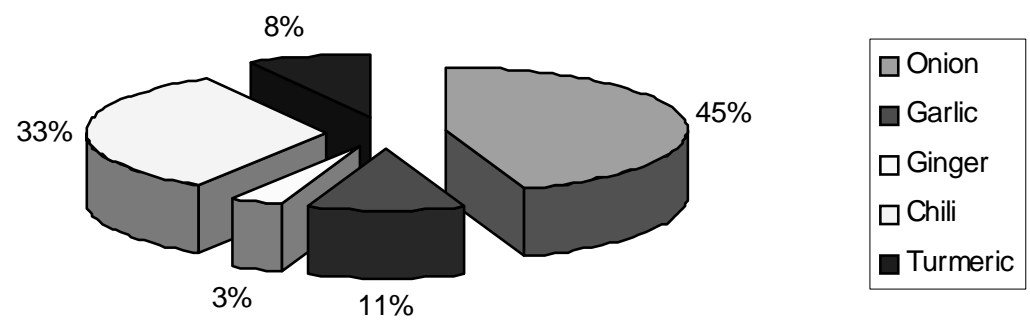

Fig. 1. Share of area cultivated under major spice crops

Table 2. Year wise summary information of key indicators of onion

\begin{tabular}{l|c|c|c|c}
\hline \multicolumn{1}{c}{ Year } & $\begin{array}{c}2001-02 \\
\text { Indicators }\end{array}$ & $2002-003$ & $2003-004$ & $2004-005$ \\
\hline Area (000' ha) & $37(100)$ & $38(102)$ & $52(140)$ & $141(381)$ \\
\% of net cultivated area & 0.46 & 0.47 & 0.65 & 1.75 \\
Production (000'mt) & $150(100)$ & $153(102)$ & $272(181)$ & $754(502)$ \\
Yield (mt/ha) & $4(100)$ & $4.03(101)$ & $5.23(130)$ & $5.35(133)$ \\
Net availability (000'mt) & $192(100)$ & $149.17(77)$ & $265.2(138)$ & $1064.87(554)$ \\
Per capita availability for & 1.5 & 1.13 & 1.98 & 7.83 \\
consumption (kg) & & & & \\
Seed requirement $\left(000^{\prime} \mathrm{mt}\right)$ & $0.11(100)$ & $0.42(382)$ & $0.43(391)$ & $0.56(509)$ \\
\hline
\end{tabular}

Source : BBS, 2004; Ministry of Agriculture GoB, 2005; Figure in parenthesis shows Index of respective indicator 


\section{Status of garlic}

Total area and production of garlic have shown in Table 3 with a positive trend over the years and it shows drastic positive change from 2003 to 2005. Percent of net cultivated area under garlic also shows increasing trend over the year. In case of productivity first time yield tends to decrease and after that it started to increase. Net availability also declined in 2002-2003 from benchmark period, and then it increased until the period of 2004-2005. Seed requirements over the year positively changed.

Table 3. Year wise summary information of key indicators of garlic

\begin{tabular}{|c|c|c|c|c|}
\hline $\mathrm{C}_{\text {Indicators }}^{\text {Year }}$ & $\begin{array}{c}\text { 2001-02 } \\
\text { (Benchmark) }\end{array}$ & $2002-003$ & 2003-004 & 2004-005 \\
\hline Area (000' ha) & $14(100)$ & 15(107) & $21(150)$ & $34(243)$ \\
\hline$\%$ of net cultivated area & 0.17 & 0.18 & 0.26 & 0.42 \\
\hline Production (000'mt) & $41(100)$ & 43(103) & $73(178)$ & 177(431) \\
\hline Yield (mt/ha) & $2.93(100)$ & $2.87(98)$ & $3.84(131)$ & $5.21(178)$ \\
\hline Net availability (000'mt) & $54.55(100)$ & $43(79)$ & $73(134)$ & 195(357) \\
\hline $\begin{array}{l}\text { Per Capita Availability for } \\
\text { Consumption }(\mathrm{kg})\end{array}$ & 0.42 & 0.32 & 0.54 & 1.43 \\
\hline Seed requirement (000'mt) & $4.20(100)$ & $14.10(336)$ & $14.10(336)$ & 17(405) \\
\hline
\end{tabular}

Source : BBS, 2004; Ministry of Agriculture, GoB, 2005; Figure in parenthesis shows index of respective indicator

\section{Status of ginger}

It is observed in the Table 4 that Ginger accounted for 0.08 percent of total cropped area, occupied 7 thousands hectare and produce 42 thousand metric ton in the benchmark period. Table 4 also shows the production and yield have increased over the year under action plan. The positive index of, production and yield over the year ensure a stable growth rate of net availability as well as per capita availability for consumption of ginger. The more area allocation to ginger leads to increase seed requirement 28 thousand metric ton to 78 thousands metric ton from benchmark to 2005 .

\section{Status of chili}

It is investigated from the Table 5 that Chili occupied 2.19 percent of the total cropped area under cultivation at the benchmark period, after that every consecutive year it's area, production and percent of net cultivated area shown cyclic patterns but yield increased with a sustained growth. Like production and area allocation, net availability also shown cyclic patterns in consecutive year. Per capita availability for consumption increased smoothly until the year 2004, and then it declined dramatically in the year 2005 due to crop failure. After the benchmark period seed requirement was same over the rest of the year. 
Table 4. Year wise summary information of key indicators of ginger

\begin{tabular}{|c|c|c|c|c|}
\hline Indicators & $\begin{array}{c}\text { 2001-02 } \\
\text { (Benchmark) }\end{array}$ & 2002-003 & 2003-004 & 2004-005 \\
\hline Area (000' ha) & $7(100)$ & $7(100)$ & $7(100)$ & $11(157)$ \\
\hline$\%$ of net cultivated area & 0.08 & .08 & 0.08 & 014 \\
\hline Production (000'mt) & $42(100)$ & $43(102)$ & $62(148)$ & 112(267) \\
\hline Yield (mt/ha) & $6.14(100)$ & $6.14(100)$ & $8.87(144)$ & $10.00(163)$ \\
\hline Net availability (000'mt) & 43.97(42.97) & $43(100)$ & $62(144)$ & $135.0(314)$ \\
\hline $\begin{array}{l}\text { Per capita availability for } \\
\text { consumption }(\mathrm{kg})\end{array}$ & 0.34 & 0.32 & 0.46 & 0.99 \\
\hline Seed requirement (000'mt) & $28(100)$ & $21(75)$ & $21(75)$ & $22(780$ \\
\hline
\end{tabular}

Source : BBS, 2004; Ministry of Agriculture, GoB, 2005; Figure in parenthesis shows Index of respective indicator

Table 5. Year wise summary information of key indicators of chili

\begin{tabular}{l|c|c|c|c}
\hline Yndicators & $\begin{array}{c}2001-02 \\
\text { (Benchmark) }\end{array}$ & $2002-003$ & $2003-004$ & $2004-005$ \\
\hline Area (000' ha) & $176(100)$ & $137(78)$ & $189(107)$ & $104(59)$ \\
\%of net cultivated area & 2.19 & 1.71 & 2.35 & 1.29 \\
Production (000'mt) & $141(100)$ & $167(118)$ & $272(193)$ & $114(81)$ \\
Yield (mt/ha) dry & $0.8(100)$ & $1.22(153)$ & $1.43(179)$ & $1.10(138)$ \\
Net availability (000'mt) & $122.45(100)$ & $141.95(116)$ & $231.2(189)$ & $96.9(79)$ \\
Per capita availability for & 0.94 & 1.08 & 1.72 & 0.71 \\
consumption (kg) & & & & $0.06(67)$ \\
Seed requirement (000'mt) & $0.09(100)$ & $0.06(67)$ & $.06(67)$ & \\
\hline
\end{tabular}

Source : BBS, 2004; Ministry of Agriculture, GoB, 2005; Figure in parenthesis shows Index of respective indicator

\section{Status of turmeric}

Area under turmeric was 16 thousands hectare in the period of benchmark which remained at 15 thousands hectare for the following two years and amusingly reached to 26 thousands hectare at 2004-05. Interestingly production remained more or less same from benchmark to 2004, then radically increased in the period of 2005 shown in the Table 6.

From the benchmark period, productivity gradually increased up to 2005. Net availability and per capita availability for consumption smoothly increased to 2003 after that dramatically increased up to 2005. Seed requirement was more or less similar after the benchmark period. 
Table 6. Year wise summary information of key indicators of turmeric

\begin{tabular}{|c|c|c|c|c|}
\hline$\overbrace{\text { Indicators }}$ & $\begin{array}{c}\text { 2001-002 } \\
\text { (Benchmark) }\end{array}$ & $2002-003$ & 2003-004 & 2004-005 \\
\hline Area (000' ha) & $16(100)$ & $15(94)$ & $15(94)$ & $26(163)$ \\
\hline$\%$ of net cultivated area & 0.19 & 0.19 & 0.19 & 0.32 \\
\hline Production (000'mt) & $43(100)$ & $44(102)$ & $43.5(101)$ & $70.7(164)$ \\
\hline Yield (mt/ha) dry & $2.69(100)$ & 2.93(109) & $2.90(108)$ & $3.84(142)$ \\
\hline Net availability (000'mt) & $37.23(100)$ & $37.4(100)$ & $60.1(161)$ & $65.6(176)$ \\
\hline $\begin{array}{l}\text { Per capita availability for } \\
\text { consumption }(\mathrm{kg})\end{array}$ & 0.28 & 0.28 & 0.44 & 0.48 \\
\hline Seed requirement ( $\left.000^{\prime} \mathrm{mt}\right)$ & $40(100)$ & $45(113)$ & $45(113)$ & $45(113)$ \\
\hline
\end{tabular}

Source : BBS, 2004; Ministry of Agriculture, GoB, 2005; Figure in parenthesis shows Index of respective indicator

\section{EXTENT OF IMPACT GENERATED BY THE ACTION PLAN}

This section deals with impact generated by action plan, which includes impact on cropping pattern, land allocation for spice crops, adoption of new varieties, yield and cropping intensity, employment and income, utilization and disposal pattern, and production practices.

\section{Impacts on allocation of land to spice crop production}

Productivity of new varieties as well as production of quality spice crops through improved management practices recommended by the action plan inspired farmers to allocating more land under spice crops. Implementation of Action Plan made a significant positive impact on land allocation to spice crops shown in Table 7.

Table 7. Allocation of land to spice crops production of the sample farmers

\begin{tabular}{l|c|c|c|c|c|c|c}
\hline \multirow{2}{*}{$\begin{array}{c}\text { Spice } \\
\text { growers }\end{array}$} & \multicolumn{3}{|c|}{ Before } & \multicolumn{3}{c|}{ After } & $\begin{array}{c}\text { Percent of } \\
\text { change }\end{array}$ \\
\cline { 2 - 6 } & $\begin{array}{c}\text { Average } \\
\text { cultivated } \\
\text { area (ha) }\end{array}$ & $\begin{array}{c}\text { Area under } \\
\text { spice crops } \\
\text { (ha) }\end{array}$ & $\begin{array}{c}\text { Percent of } \\
\text { area under } \\
\text { spice crops }\end{array}$ & $\begin{array}{c}\text { Average } \\
\text { cultivated } \\
\text { area (ha) }\end{array}$ & $\begin{array}{c}\text { Area under } \\
\text { spice crops } \\
\text { (ha) }\end{array}$ & $\begin{array}{c}\text { Percent of } \\
\text { area under } \\
\text { spice crops }\end{array}$ & \\
\hline Onion & 1.03 & 0.13 & 12.56 & 1.03 & 0.18 & 17.50 & 36.6 \\
Garlic & 1.44 & 0.06 & 4.20 & 1.44 & 0.11 & 7.50 & 80 \\
Ginger & 1.20 & 0.06 & 5 & 1.20 & 0.09 & 7.40 & 46.7 \\
Chili & 1.49 & 0.04 & 2.8 & 1.49 & 0.07 & 4.40 & 57 \\
Turmeric & 1.57 & 0.03 & 2.06 & 1.57 & 0.06 & 3.80 & 87.5 \\
\hline
\end{tabular}

Source : Field Survey, 2006 
It was observed from the analysis in the Table 7 that highest percent of change for land allocation found (87.5\%) in case of Turmeric followed by Garlic, Chili, Ginger and Onion accordingly. Whereas percent of area utilization for Garlic and Chili growing were increased twice times compared before action plan. Here, second highest percent of positive change in area allocation to spice was found in case of Garlic as well and the least percent of positive change found $39.6 \%$ count for area allocation to Onion.

\section{Impact on adoption of new varieties}

\section{Coverage of varieties}

One of the strategies of Action Plan was the area under spice crops transform into new improved varieties coverage. In this study, an attempt was made to quantify the extent of adoption of improved varieties by the sample spice growers. Interestingly farmer's perception about the new varieties was very impressive, they want to cultivate 100 percent of spice lands with new varieties. But due to unavailability of quality seed, coverage of area with new varieties still sub-optimal. It was observed that area coverage was higher for turmeric grower's who adopted new varieties more than other four spice crop growers. Because the supply of quality seed to the farmer by DAE under the Action Plan, made a tremendous effect on the availability of quality seed. On the other hand farmers retain seed intensively used next year subsequently. The onion growers found as a second highest adopter of new varieties in the study area. They were more or less acquainted with improved varieties before implementing Action Plan. After introducing seed village program under action plan, area coverage with improved varieties of onion significantly increased but due to complex seed production technique there is no scopes for used farmers retain seed next time. Before Action Plan sample garlic producer's area were not under improved varieties, after motivation and supply of improved seed with extension materials variety coverage increased to 32 percent. Chili producer successfully increased improved variety coverage from 2 to 27 . Improved variety coverage of ginger growers was very low because of improved variety was not still introduced at farmer level. They used locally developed varieties.

Table 8. Farmer's adoption of improved varieties

\begin{tabular}{l|c|c|c}
\hline \multirow{2}{*}{ Spice } & \multicolumn{3}{c}{$\begin{array}{c}\text { Percent of area used of the total by the sample spice grower under } \\
\text { improved varieties }\end{array}$} \\
\cline { 2 - 4 } & Before & After & Change (\%) \\
\hline Onion & 26 & 67 & 41 \\
Garlic & 0 & 32 & 32 \\
Ginger (locally improved) & 3 & 9 & 6 \\
Chili & 2 & 27 & 25 \\
Turmeric & 0 & 76 & 76 \\
\hline
\end{tabular}

Source : Field Survey, 2006 


\section{Impact on yield and cropping intensity}

Table 9 shows that the impact of yield of spice crops and its cropping intensity. It was observed that the highest percent of yield increased for Turmeric accounted 66\%; and least per cent of yield increased accounted 6\% and 6.5\% for Garlic and Ginger respectively due to absence of early rain and lack of availability of improved varieties in field level. These facts hampered the productivity of spice crops up to optimum level.

Table 9. Yields of spice crops and intensity of land use of the sample spice growers

\begin{tabular}{l|c|c|c|c|c|c}
\hline \multirow{2}{*}{$\begin{array}{c}\text { Spice } \\
\text { growers }\end{array}$} & \multicolumn{3}{c|}{ Yield (kg/ha) } & \multicolumn{3}{c}{ Cropping intensity (\%) } \\
\cline { 2 - 7 } & Before & After & Percent of change & Before & After & Percent of change \\
\hline Onion & 8976 & 11968 & 33 & 189 & 205 & 15.57 \\
Garlic & 2825 & 2992 & 6 & 187 & 188 & 1.07 \\
Ginger & 10842 & 11556 & 6.5 & 198 & 208 & 10.74 \\
Chili & 8377 & 11968 & 42 & 198 & 209 & 11.17 \\
Turmeric & 8984 & 14950 & 66 & 182 & 198 & 15.85 \\
\hline
\end{tabular}

Source : Field Survey, 2006

Again it was appeared that the percentage change in cropping intensity was higher for Turmeric and Onion and the lowest for Garlic accordingly. Improved seed, close supervision by the DAE under Action Plan motivate farmers towards intensive utilization of cropland, homestead area and fallow land under spice cultivation.

\section{Impact on employment and income of the spice growers}

Commercial motivation of spice crop cultivation in rural areas starts to use more hire labor than before. Thus Action Plan contributes positively to rural employment especially for chili cultivation where poor women were engaged in priming of chili at the rate of Tk. 1 to 2 per $\mathrm{Kg}$.

\section{Impact on agricultural income}

The study also attempted to analyze the contributions of action plan of spice crop in the farms agric income shown in the Table 10. It was found that the spice crops significantly increase percent of total agric income after implementation of Action Plan. The average income from all spice crops in the study area increased from benchmark period shown in the Table 10.

\section{Impact of training on spice production practices}

The farmers were received a daylong training on improved production practice, post harvest operation, storage method and seed production techniques Under Action Plan. It was observer that percentage of knowledge received from training was moderately high for five major spice crops. At the same time adoption rate also satisfactory for all technology at farm level in the study shown in the Table 11. The Action Plan contributes 
to improved knowledge base of spice production, storage, as well as seed production techniques in field level.

Table 10. Share of spice crop income to agricultural income in the study area

\begin{tabular}{l|c|c|c|c|c}
\hline \multirow{2}{*}{$\begin{array}{c}\text { Name of } \\
\text { spices }\end{array}$} & $\begin{array}{c}\text { Net returns } \\
\text { (Tk./ha) }\end{array}$ & \multicolumn{2}{c|}{$\begin{array}{c}\text { Average income from spice } \\
\text { (Tk./ Farm) }\end{array}$} & \multicolumn{2}{c}{ Percent of total agric income } \\
\cline { 3 - 6 } & & Before & After & Before & After \\
\hline Onion & 38281 & 3425 & 6509 & 2.5 & 9.3 \\
Garlic & 50281 & 2720 & 4885 & 1.3 & 3.9 \\
Ginger & 282011 & 25700 & 39961 & 1.1 & 3.3 \\
Chili & 71441 & 3500 & 9544 & 2.8 & 5.8 \\
Turmeric & 65423 & 2645 & 5297 & 1.3 & 2.5 \\
\hline
\end{tabular}

Source : Field Survey, 2006

Table 11. Extent of knowledge base and adoption rate of improved technology by the sample spice grower under action plan

\begin{tabular}{l|c|c|c|c|c|c}
\hline \multirow{2}{*}{$\begin{array}{c}\text { Technologies } \\
\text { crops }\end{array}$} & \multicolumn{2}{|c|}{ Production technique } & \multicolumn{2}{c|}{$\begin{array}{c}\text { Post harvest operation } \\
\text { and storage }\end{array}$} & \multicolumn{2}{c}{ Seed production } \\
\cline { 2 - 7 } & $\begin{array}{c}\text { Reception } \\
\text { (Percent) }\end{array}$ & $\begin{array}{c}\text { Adoption } \\
\text { (Percent) }\end{array}$ & $\begin{array}{c}\text { Reception } \\
\text { (Percent) }\end{array}$ & $\begin{array}{c}\text { Adoption } \\
\text { (Percent) }\end{array}$ & $\begin{array}{c}\text { Reception } \\
\text { (Percent) }\end{array}$ & $\begin{array}{c}\text { Adoption } \\
\text { (Percent) }\end{array}$ \\
\hline Onion & 75 & 68 & 89 & 72 & 27 & 18 \\
Garlic & 82 & 53 & 92 & 90 & 76 & 65 \\
Ginger & 61 & 49 & 43 & 37 & 88 & 67 \\
Chili & 92 & 90 & 68 & 54 & 45 & 40 \\
Turmeric & 95 & 91 & 56 & 47 & 89 & 87 \\
\hline
\end{tabular}

Source : Field Survey, 2006

\section{COST REVENUE STRUCTURE AND PROFITABILITY OF SPICE CROPS PRODUCTION UNDER ACTION PLAN}

To get a thorough understanding about a production system financial profitability is an important indicator. The present study analyzed the farm business through enterprise costing of spice crops. Results of the financial profitability are presented in Table 12.

Table 12 shows that per hectare yield, costs and return of the spice crops under the action plan. Among all types of spices crops, Turmeric had the highest yield of $14950 \mathrm{~kg}$ per hectare whereas Onion, Chili and Ginger had the next highest yield of 11,968 kg, 11,968 $\mathrm{kg}$ and 11,556 kg per hectare accordingly; and the least yield was in the Garlic accounted $2992 \mathrm{~kg}$ per hectare. But surprisingly, Gross margin, which represented the difference between gross return and variable cost, was highest for Chili followed by Turmeric and 
Garlic respectively. Although the yield of Chili was lower than Turmeric but gross margin was the highest due to fluctuation of price in the market.

Table 12. Summary results of costs and returns and profitability of spice crops

\begin{tabular}{|c|c|c|c|c|c|c|}
\hline \multirow{2}{*}{$\begin{array}{l}\text { Sl. } \\
\text { No. }\end{array}$} & \multirow[t]{2}{*}{ Particulars } & \multicolumn{5}{|c|}{ Yield, costs and returns by spice } \\
\hline & & Onion & Garlic & Ginger & Chili & Turmeric \\
\hline 1 & Yield (kg) & 11968 & 2992 & 11556 & 11968 & 14950 \\
\hline 2 & Price (Tk./kg) & 15 & 32 & 35 & 12.50 & 11 \\
\hline 3 & Value of output (Tk.) & 179520 & 97240 & 404460 & 149600 & 159600 \\
\hline 4 & Value of by-product (Tk.) & 1200 & - & - & - & - \\
\hline 5 & Gross return (Tk.) & 78465 & 97240 & 404460 & 149600 & 164450 \\
\hline 6 & Gross costs (Tk.) & 40184 & 46959 & 122449 & 78159 & 99027 \\
\hline 7 & Variable costs (Tk.) & 30564 & 39793 & 81537 & 59834 & 85514 \\
\hline 8 & Gross margin (Tk.) & 47901 & 57447 & 322923 & 80766 & 78936 \\
\hline 9 & Net return (Tk.) & 38281 & 50281 & 282011 & 71441 & 65423 \\
\hline 10 & $\begin{array}{l}\text { Benefit-cost ratio } \\
\text { (Variable cost basis) }\end{array}$ & 2.57 & 2.44 & 4.96 & 2.50 & 1.92 \\
\hline 11 & $\begin{array}{l}\text { Benefit-cost ratio } \\
\text { (Total cost basis) }\end{array}$ & 1.95 & 2.07 & 3.30 & 1.91 & 1.66 \\
\hline 12 & $\begin{array}{l}\text { Cost per unit output } \\
\text { (Variable cost basis) }\end{array}$ & 5.96 & 13.29 & 7.05 & 4.99 & 5.72 \\
\hline 13 & $\begin{array}{l}\text { Cost per unit output } \\
\text { (Total cost basis) }\end{array}$ & 7.84 & 15.69 & 10.59 & 6.53 & 6.62 \\
\hline
\end{tabular}

Source : Field Survey, 2006

Per hectare gross cost of the spice crops have high variation, and ranged from Tk. 1,22,449 to Tk. 40,184 for Ginger to Turmeric as well. Production of all types of spice crop was profitable as was indicated by return of more than taka 1 for each taka invested in variable and total cost basis but the highest was for Ginger accounted 4.96 and 3.30 (variable and total cost basis) whereas the lowest for Turmeric accounted 1.92 and 1.66 variable and total cost basis accordingly.

Consequently, net margin was the highest for Gingers (Tk. 2,82011) followed by Chili (Tk. 71441) and Turmeric (Tk. 65423) accordingly. It appeared from the table that gross margin and net return of ginger were higher than those for all other spice crops. Yet gross margin and net return was gradually decreased for onion.

\section{CONCLUSIONS AND RECOMMENDATIONS}

The study was under taken to evaluate impact of different research and extension services for increasing spice crop production though an integrated approach. This 
integrated approach under the umbrella of Action Plan made a series of impact both national as well as grassroots level production system of spice crop. Status of spice crops positively changed after the implementation of action plan showing the moderate increased in yield, production and area allocation over the period of time.

Result of the study showed that knowledge base of the farmer through training, motivation and supply of extension materials impact on productivity, area allocation, disposal pattern as well as income of the farmer. At the same time profitability and favorable benefit-cost ratio of the spice crop significantly increase production in the study area.

The crop based research and extension is a continuous process, it needs to prolong up to a matured level where improved variety coverage and production practices sustain at farm level over a period of time. Spice crop based research and action plan are also a part of this process. Whereas government of Bangladesh has taken step named "Action Plan for Spice Crops Production" increasing further 25\% spice crops by 2005, it is not yet matured enough to a sustain improved seed and production practices at farm level independently. But there is still necessary to have further intervention of more than five years for sustaining the gain of previous effort. At the same time from above findings and discussions, the following recommendations may be provided for covering more area with new varieties for more production:

1. Strengthening institutional linkages, continuation of research, development and extension services with higher training facilities for the scientist, field worker, as well farmers. All program should ensure involvement of multidisciplinary expertise in plant breeding, Agronomy, Plant pathology, Entomology, Seed science and Economics.

2. Present area under spice crops must be replaced by the improved varieties through out the country. To ensure improved variety coverage, infrastructure for seed production and technology need to transfer most receptive farming community through GO, NGO linkages.

3. Create awareness about the profitability of spice crops to the potential farmers. A multidimensional motivation program about spice crops production needs to develop through leaflet, poster, radio, television and farmer's club.

4. Commitment by the government to provide seed, aid, other extension materials and training in time to the farmers for increasing production to the target level.

5. Rich knowledge base and experiences on various aspect of improved spice production techniques including germ plasma technology is very limited in Bangladesh. Effort should be made for training up scientist from abroad where spice crops intensively grown.

Keeping other factors remaining same the Action Plan should be continued with a perspective plan for sustaining it to a stable position. 


\section{REFERENCES}

Alam, J. 2005. Enhancing Sustainable Development of Diverse Agriculture in Bangladesh, Economic and Social Commission for Asia and Pacific- a working Paper, UNESCAP-CAPSA, Working paper series No.80, Indonesia.

Bangladesh Bureau of Statistics 2004. Year Book of agricultural Statistics, Statistics Division, Ministry of Planning, Dhaka.

Bangladesh Bureau of Statistics, 2004. Statistical Yearbook of Bangladesh, Statistics Division,, Ministry of Planning, Dhaka.

Elias, S. M. and Hossain, M. I. 1984. Chili cultivation in Bangladesh : Agro-economic Survey and Constraints to its Higher Production at Farm Level, Gazipur: Bangladesh Agricultural Research Institute.

National Technical Working Group, 2005. Action Plan for Increasing the Production of Spices Crop to further 25\%, Ministry of Agriculture, Peoples Republic of Government of Bangladesh.

Rahman, M. M. 1993. An Economic Study of Resource Use Efficiency, Women Labour Employment and Income Generation Potentials of Farmers Practicing Homestead-Agro-Forestry in Bangladesh, Report submitted to Winrock International, Dhaka.

Spices Research Centre, 2005. Production technology of spice crops, Bklt-01/2005. Bangladesh Agricultural Research Institute, Shibgonj, Bogra. 